Running head: USES OF MEANINGFULNESS

\title{
Serving Time: Volunteer Work, Liminality and the Uses of Meaningfulness at Music Festivals
}

Toraldo, M.L., Islam, G. \& Mangia. G. (2018) Serving time: Volunteer work, liminality and the uses of meaningfulness at music festivals. Journal of Management Studies, onlinefirst

\begin{abstract}
Drawing from a participant-observer study of volunteering in the context of U.K. music festivals, we examine how the sense of meaningfulness and community relate to instrumental goals of consumption and efficiency. We argue that the liminal nature of the festival setting supports an ambivalence in which meaningfulness is established through constructions of community, while the commodification of community feelings leads to heterogeneous understandings of the work setting. Our findings reveal heterogeneous ways in which work was rendered meaningful by festival volunteers, ranging from 1.) A commodity frame, characterizing work as drudgery seeking "fun" through consumption 2.) A "communitas" frame, emphasizing a transcendental sense of collective immediacy and 3.) A cynical frame, where communitas discourse is used instrumentally by both managers and workers. We discuss meaningful work as caught between creative community and ideological mystification, and how alternative workspaces vacillate between emancipatory principles of solidarity and neo-normative forms of ideological control.
\end{abstract}

Key words: Meaningful work, volunteer, liminality, ideology, ethnography

Acknowledgements: The authors would like to acknowledge and thank Marcos Barros, Nada Endrissat, and the members of the MOTI seminar for their close readings and in-depth comments on previous versions of this manuscript, as well as the detailed comments by the special issue editors Catherine Bailey and Adrien Madden and reviewers at JMS. 
"When power wants to make people forget, music is ritual...when it wants them to believe, music is enactment, representation; when it wants to silence them, it is reproduced, normalized." Attali 2009:20

"Morning: work at Park. Conversation with Rudi around chakras and colour energy. I cleaned the toilets." Sutcliffe, 2003:168

Contemporary work is increasingly marked by discourses of meaningfulness, self-expression and personal fulfilment (e.g. Bailey, Madden, Alfes, Shantz \& Soane, 2016; Brannan, Parsons \& Priola, 2015; Fleming, 2009). Combining work and personal satisfaction with a critique of bureaucratic "traditional" work, contemporary organizations imbue labour with a new meaningfulness, inciting both praise and cynicism (Endrissat, Islam \& Noppeney, 2015; Fleming \& Spicer, 2007). While meaningful work is existentially fulfilling and personally satisfying (Shershow, 2005), it also brings up issues of control around the encroachment of organizations into the private sphere (Bailey et al, 2016). Especially where work is unpaid, invisible or precarious (e.g. O’Toole \& Gray, 2015), meaningfulness may obscure inadequate working conditions and the instrumentalization of social relations for economic ends. Increasingly, scholars are noting how the "new spirits" (Du Gay \& Morgan, 2013) of self-expressive and meaningful work, demonstrate tensions between emancipation and new forms of ideological control (e.g. Bailey et al., 2016; Fleming \& Sturdy, 2011; Bunderson \& Thompson, 2009), by which positive work climates are promoted instrumentally to mask workplace exploitation. This work increasingly questioned how such tensions in workplace meaningfulness are experience in practice by workers (Mitra \& Buzzanell, 2017; Endrissat et al, 2015; Ekman, 2014).

Considering meaningfulness as a source of workplace control and commodification is particularly salient where work involves the liminal aspects of society: the transitory, in-between spaces where norms are symbolically bracketed and alternative configurations of meaningfulness can emerge (e.g. Shortt, 2015; Dale \& Burrell, 2008; Turner, 1969). Looking to liminality recognizes that meaningfulness is not only a question of work tasks, but of the way that work is positioned in relations of social production consumption, and collective life more generally. Liminal spaces mark the interstices of social structures and point towards the limits of society, yet also are moments of renewing the social; as both a ground and limit to the social, liminal spaces are described as central to establishing a sense of collective unity or "communitas" (Esposito, 2013; Turner, 1969).

However, in situations where social interactions are the basis for productive economic activity, liminality may open up "spaces for capital” (Harvey, 2001), where meaningful collaboration supports capital accumulation. Early theorizing on liminality (Turner, 1969) in rituals and festivals recognized this ambivalence between communitas and control, an ambivalence which parallels tensions described in the meaningful work literature (e.g. Bailey et al, 2016; Bunderson \& Thompson, 2009). This ambivalence is at 
the core of liminality. On the one hand, liminality represents the limits of the everyday, and is used in ritual to mark a utopian outside of authentic communal experience and meaningfulness (Lips-Wiersma \& Wright, 2012; Islam, 2015). On the other hand, harnessing liminality through ritualized spaces and ceremony is a quintessential part of social control (Tuner, 1969; see also Cohen, 1985). Festival volunteer work (cf. Lucas, 2014; Chen, 2009) provides an ideal context for understanding how the ambivalence of work in liminal spaces is experienced in practice.

Festivals operate on the frontier between work and pleasure, tight organization and "creative chaos" (Chen, 2009). Festivals are temporary, mobile and focused on the expression of desire and communal celebration (Toraldo \& Islam, 2017; Parker, 2011). This liminal character of festivals most probably influences work experiences, as scholarship around liminality at work suggests (e.g. Shortt, 2015; HowardGrenville, Golden-Biddle, Irwin, \& Mao, 2011; Sturdy, Schwartz \& Spicer, 2006). While liminality involves communitas (Esposito, 2013; Turner, 1969), evoking feelings of transcendence and unity that are closely aligned with current conceptualizations of meaningfulness (Lips-Wiersma \& Wright, 2012), we know little about the ambivalence of communitas as a source of both meaningfulness and exploitation. With this objective in mind, we explore the research question: How does festival work create opportunities for meaningful experience, and how are the ambivalent features of such work experienced in practice?

To address the ambivalence of meaningful work, we report the results of a case study of music festival volunteering, exploring how otherwise tedious and exploitative work may be experienced as meaningful, enlightening or socially valuable. Studying festival volunteers (i.e. workers receiving only free entry or other nominal compensation), allows us to examine how work is experienced as being rewarding for participants, while simultaneously entrenching forms of control by ideologically masking work's economic instrumentality (O’Toole \& Grey, 2015). Although volunteering is not historically a new phenomenon, examining volunteering work can reveal insights for contemporary labour transformations on the dimensions of temporary work, liminal work and community-oriented practices (O’Toole \& Grey, 2015).

The rest of the paper is structured as follows. First, we discuss the ambivalence of meaningful work in its relation to new forms of normative control, and we describe how festival spaces frame liminality to affect the work experience. Liminality, associated with a sense of social unity or communitas, draws volunteers to festival work and rationalizes volunteers' willingness to work without pay (e.g. Barron \& Rihova, 2011). Next, we describe the findings of an in-depth, participant-observer study of three U.K.based music festivals, where communitas was used by organizers to infuse meaning into work and to obscure its monotony, while volunteers used communitarian rhetoric to build relational bonds and reframe consumption practices as socially-conscious action. Finally, we discuss our findings' implications for 
understanding meaningful work within liminal spaces, offering resources to understand ideological control at work, while evaluating the emancipatory possibilities for meaningful work.

\section{The Ambivalence of Meaningful Work}

Meaningful work is characterized as being "particularly significant and holding more positive meaning for individuals" (Rosso et al., 2010: 95), and is of growing interest to management scholars (Bailey et al 2017; Yeoman, 2014a; 2014b; Dempsey and Sanders, 2010; Lips-Wiersma and Morris, 2009).

Although interest in meaningfulness itself is not new, its challenge to traditional bureaucratic control is attracting renewed attention (e.g. Aguinis \& Glavas, 2017; Bailey \& Madden, 2017). This is particularly so in contemporary work settings that are both sources of self-expression and also marked by precarity (cf. Petriglieri, Ashford \& Wrzesniewski, 2018; Vallas \& Prener, 2012). How to think of meaningfulness in the instability of "liquid" modernity (Bauman, 2000) is an ongoing question. Increasingly, scholars are exploring the emancipatory possibilities of meaningful work (e.g. Aguinis \& Glavas, 2017; Yeoman, 2014b), while some are investigating its relation to exploitation, eroding work conditions and the commodification of social relations (Endrissat et al 2015; Gill \& Pratt, 2008).

Managerial responses to the "crisis of the quality of work" (Castillo, 1997, p. 416) involve a turn to humanistic, social and creative initiatives, which may provide ideological cover for persistent wage depression and job instability (Endrissat et al, 2015; Kalleberg, 2009). Meaningful work opens up the possibility of self-fulfilment but also the danger of workplace control (Bailey et al, 2017). Indeed, workplace mystification practices involving promises of workplace happiness (Jenkins \& Delbridge, 2013), personal authenticity (Fleming \& Spicer, 2007) or social responsibility (Mitra \& Buzzanell, 2017) have characterized the ambivalence of meaningfulness at work. Less is known, however, about how liminal events such as festivals shape techniques of control and experiences of the meaningfulness of work.

Festival work, often in the form of volunteering programs (e.g. Bachman, Backman \& Norman, 2014), paradigmatically illustrates the tensions of meaningful work (e.g. Mitra \& Buzzanell, 2017; Mitra \& Fyke, 2017). Because the compensation involved is largely symbolic, control mechanisms tend to be cultural or normative (O’Toole \& Grey, 2015). Emphasizing intrinsic, value-based motivation, but also requiring organizational control over inputs (cf. Ekman, 2014), volunteering presents a paradox of managerial control (O’Toole \& Grey, 2015; la Cour \& Højlund, 2008). Such work is highly sensitive to interpretations by workers and managers (DeVoe \& Pfeffer, 2007). The almost complete absence of material compensation and the extreme flexibility of some volunteer programs make them ideal cases for examining neo-normative workplace control, particularly when the programs are centered around messages of collective unity, authenticity and self-realization. 


\section{Festival Work, Liminality and Communitas}

Liminality relates to volunteering because work and non-work spheres are blurred in volunteering, paralleling the ambiguity of meaningful labour more generally. In meaningful labour, work is symbolically inflected with features invoking peak experiences, such as personal relationships or connection with existential themes (e.g. Bailey \& Madden, 2016). Bailey \& Madden (2017), for example, note how meaningful work creates a sense of unity across temporal landscapes, uniting past, present and future. Endrissat et al (2015) show how uniting work and self-expression "enchants" otherwise mundane service work, creating meaningfulness by blurring production-consumption boundaries, while Ekman (2012) argues that a "limitless potential" rhetoric in creative work drives fantasies supporting neo-normative worker control. In each case, work draws opportunistically upon meaningful non-work spaces to obfuscate labour processes, yet simultaneously creates conditions for the experience of meaningfulness.

Festival work, similarly, straddles the boundary between work and social life, making it paradigmatic of "modern working cultures" (Fineman, 2012: 2). Festivals draw on feelings of social solidarity (Toraldo \& Islam, 2017), resonating with meaningful work's emphasis on unity with others (Lips-Wiersma \& Morris, 2009). Creative working contexts associated with music and aesthetics are perceived as being selfexpressive and creativity-enhancing (Neff et al, 2005), similarly to Lips-Wiersma \& Morris' (2009) dimension of self-development and becoming. Festivals often stress political activism, invoking countercultural overtones (Johansson \& Toraldo, 2015; Chen, 2009). Yet, as temporary and unsettled (Chen, 2009), festivals are also characterized by short-term, low-wage and unstable arrangements, while marketing themselves based on emotional connection and creativity (Raunig et al., 2011; Beverungen et al., 2013; Land and Taylor, 2010). Festival volunteering thus mingles unpaid and intensive work with evocations of communal living practices (Parker, 2011).

As transitory moments, geographically separated from ordinary life, festivals symbolically gesture toward the limits of social control, a space in which transgression, desire or even subversion are temporarily licensed (Toraldo \& Islam, 2017; Islam, Zyphur \& Boje, 2008). As is the case with carnivals or circuses, festivals take place in unstable times and places (Parker, 2011), and may throw stable norms into doubt (Bakhtin 1984). As Parker (2011) points out, such seemingly transgressive spaces can either unsettle or reinforce dominant ideologies.

The liminal aspect of festivals (e.g. Turner, 1969; van Gennep, 1905), derives from this quality of being bracketed off from everyday norms, and of serving as an in-between space. Whilst they exist at the interstices of social orders, liminal spaces are described by Turner (1969) as being instrumental in creating a sense of "communitas" that is constitutive of meaningful social action. Communitas constitutes the "anti- 
structural" basis of the social fabric, the aspect of social togetherness preceding and forming the condition of possibility for formal institutions (Turner, 1969). Communitas, as the relational glue holding social orders together, is experienced as deeply meaningful (cf. Lips-Wiersmas \& Morris'[2009] dimension of "unity with others") ; yet, as "anti-structural", it also potentially constitutes a threat to established orders. Both prosocial and anti-institutional (Esposito, 2013), communitas is socially and symbolically constructed (Cohen, 1985). Communitas is harnessed and controlled through ritual enactments within which it is given free reign, periodically renewing the sense of social unity and containing social disintegration.

In this context, the recent spread of festivals as commodified events (Johansson \& Toraldo, 2015; Chen, 2009), and their heavy utilisation of temporary labour such as volunteers, raises questions of how actors manage and negotiate the meaningfulness embedded in such spaces, and whether festivals' liminality is an emancipatory opening toward meaningful work or, alternatively, a source of neo-normative control (cf. Bunderson \& Thompson, 2009). As highly-profitable spaces with easily-exploitable labour, festivals act as spaces for capital accumulation (Harvey, 2001), an aspect obfuscated by the countercultural messages abounding at festivals. Festivals are often experienced as sources of authentic collective experience (Clark \& Jepson, 2011) and identity construction (Prentice \& Anderson, 2003). However, the commodification of "authenticity" and the rise of music tourism (e.g. Getz, 2010) mean that straightforward readings of festivals as cultural rituals may overlook the instrumental and ideological uses of "community". In this reading, authenticity and collective identity may function discursively to blur work/non-work boundaries (Chen, 2012), attracting volunteers willing to work for low or even no remuneration.

In short, festivals constitute arenas where collective sentiments of communitas may arise out of the liminality of the festival space. This sense of communitas, by producing satisfaction and a sense of togetherness, may be commodified and used to motivate labour. This substitution of concrete benefits by meaningfulness has been noted in recent management literature (e.g. Brannan et al, 2015; Endrissat et al, 2015; Bunderson \& Thompson, 2009), and is a feature of contemporary work more generally. Indeed, festival work exemplifies this trend and highlights its dependence on liminality. Rather than categorizing the festival volunteer experience, a priori, as commodification or communitas, we follow Mackellar (2013) in stressing the need for in situ qualitative research on festival organizations, focusing on experience from the actors` point of view. Focusing on the felt dynamics of volunteer experience, we address the question of how festival work is rendered meaningful by organizers and workers, and how attempts to produce meaningfulness are received and interpreted by participants.

\section{Research Settings and Methods}


From an in-depth exploratory study based on ethnographic investigation, we focus on three U.K. music festivals (Latitude Festival, Camp Bestival and Reading Festival). Beginning from the ontological and epistemological premises that actors co-construct their organizational reality through their diverse positions, and that on-the-ground critique holds potential for academic theorization, we set out to explore this diversity of positions through in situ observation and participation.

The first author entered the field as a volunteer via festival suppliers - that is, companies providing services to festival events. Sampling involved gathering information on leading volunteers' suppliers operating in the festival business. We consulted specialised on-line platforms on festivals (e.g. efestival) and main UK newspaper inserts. About twenty-five providers were contacted via emails and three contacts were established, including two not-for-profit (Recycling First and Bars for Equality) and one for-profit (Baristas) companies, which were involved in diverse activities (recycling, bar provision, stewarding) and all of which employed volunteers. After an initial contact with the Volunteers' Staff Coordinator at the for-profit organization, permission was granted to the first author to register as a bartender via the online booking system and to volunteer at one of the festivals where the company provided bar services and staff. She was recruited to bar tend at Camp Bestival, and received an information package with details about check-in time, event shifts and breaks, uniforms and camping. The two not-for-profit companies were accessed after a preliminary conversation with managers and staff organisers about the research objectives. Festival access was given by the three providers, and the volunteers working with the fieldworker were informed about the research at the outset of the fieldwork.

The first author volunteered as a bartender and litter picker, which are among the most common volunteer positions. The bartending involved two providers (for-profit and not-for-profit) and litter-picking involved a not-for-profit organisation. Both for-profit and not-for-profit suppliers serve the festival - and volunteers from both types of organization were included in the analysis. Across cases, service arrangements with festivals followed a similar scheme: providers were paid directly by the festival, which externalised the provision of basic services and management. Both types of providers were paid a fee for each volunteer they provided, based on the volunteer's hourly work.

Because our focus was on the volunteer experience rather than organizational form, we focused on the heterogeneity of experiences around the work, rather than on the organization types. Broad commonalities were observed across organizations, as suppliers managed recruitment strategies and working practices, defining shifts, uniforms, infrastructure and work organization. These suppliers represented the interfaces through which volunteers accessed the festival in the positions of steward, bartender, camping assistant team, environmental monitor and litter picker. After choosing the provider and the job role, 
volunteers specified shift preferences and completed the "friend section" of an online form, where they could request to work with friends. Organizers explained that matching friends together was important for recruitment, and that it provided a motivating feeling of togetherness.

When applying, volunteers paid a deposit - normally equal to the price of a festival ticket and refundable, minus transaction costs, after the event - as a guarantee for turning up and completing their shifts. Volunteer provision was largely regulated by full service-level agreements between festival organisers and providers, specifying service types and legal responsibilities. Regardless of organizational type (profit or not-for-profit), the volunteer offering is understood as a commercial transaction but, for the not-for-profit organizations, funds are reinvested in the organization or in social causes. The different organizational forms co-existed at the festival, and volunteers from both often worked side-by-side, blurring organization-level differences in work experience. Volunteers normally arrived the previous day, checked-in to a camping area and set up tents in the backstage area. A village-like atmosphere was achieved by the coexistence of numerous volunteers mingling in the fenced area after their shifts.

Volunteers typically worked daily shifts of 6-8 hours, in groups of 4-6 with a supervisor, receiving free tickets, staff camping and food vouchers in return. At the team briefing, workers were informed about the sign in-off location for their shifts, and of the requirements of wearing a tabard (uniform) and crew wristband. Requirements and responsibilities varied across providers. Finally, workers received last-minute instructions at each provider's headquarters in the staff camping area.

Data collection involved participant observation and formal and informal interviews at the festival (cf. Mackellar, 2013, on festival research methods). The fieldworker engaged in all relevant pre-, during and post- festival volunteer activities, remaining close to more seasoned volunteers in order to "shadow" the volunteers as much as possible. Data were recorded manually in a diary each day (4-7 days/nights per festival, resulting in over 100 pages of written diary), describing observations and conversations.

Observations were structured via tags ("observational notes", "theoretical notes", "methodological notes"), and episodes and different voices from the field were recorded. Some notes were written while the researcher was working with fellow volunteers; others were written retrospectively when note-taking was impossible. The fieldwork was complemented by 7 formal interviews (1-2 hours each) with non-volunteer managers of the different service organizations; these were digitally-recorded. Respondents were asked questions on processes and procedures of the service: questions designed to explore the recruitment and management of volunteers, the typical feedback received from volunteers and interactional dynamics both among volunteers and with management. Photos, widely taken as supporting documentation during all phases, are included below for illustrative purposes, although we do not engage in a specific visual coding or 
interpretive analysis (e.g. Rose, 2001) as a basis for argumentation. We summarize our data sources and their use in our analysis in Table 1.

\section{Insert Table 1 about Here}

The data analytic strategy involved iterating between the initial research question about the experience of volunteer work in practice, concepts from the literature and emerging themes from observations and transcribed interviews over several phases, via a process of "constant comparison" (cf. Gibbert \& Ruigrok, 2010). First, we broadly examined the data for themes regarding volunteer work experience, noting a focus on community orientation and the uniqueness of the festival setting. We focused our attention on this community aspect, searching for categories from the academic literature to analyze the ambivalence and social effects of liminality, noting that reactions to the volunteer work were heterogeneous, yet seemed to coexist in relative harmony. This led us to focus on the reflexive standpoints taken by the respondents (cf. Endrissat et al, 2015) to capture ambivalence, focusing on bottom-up critique where relevant (Bourdieu, 1990). For instance, while two respondents may mention authenticity, one might mention it as a work feature, and other as an ironic joke or a criticism, which we would note. Table 2 lists the main analytical themes and sub-themes, with illustrations from the data.

Table 2 about Here

As described below, double-meanings, lapses and self-contradictions were common in respondents' discourses, and we organized our findings to represent these contradictions. In order to establish a critical distance vis-à-vis a given framing and focus on the respondents' interpretations, our results describe both their descriptions of work and the diverse reflexive or critical standpoints taken toward the work. The resulting analysis led to three contested framings of the festival work, explored below (see Table 3). Through reflecting diverse critical standpoints and kinds of reflexivity around volunteering, each frame is conceptually related to, and in tension with, the others; we expand on this in the discussion section. Yet, as analytically separated through the coding process, we present each standpoint separately.

Table 3 about Here

Work as commodity: Drudgery in Work versus Amusement in Consumption 
In contrast to the sense of celebration promoted during recruitment around the festival experience, workers often reported tasks as being tedious, boring and alienating. Similar to the notion of work as disutility and commodity (Budd, 2011), volunteers worked in order to finish and engage in consumption activities, regarded as compensation for the work's drudgery. Experienced as a commodity to be extracted from workers, work was seen to be coerced through external control and surveillance. Conceptually distinct but consistent with such a description, work was experienced as drudgery and monotony, and its standardization was lamented. In the commodity frame, participation was purchased at the price of work. We identified three prevalent sub-framings: 1.) The commodity nature of volunteer work, 2.) The monotony and drudgery of work and 3.) The trade-off between work and fun or consumption.

\section{Volunteering as Commodification and Control}

Volunteers often described their work with metaphors invoking industrial, money-related images of labour, and complained about the standardized or industrial nature of the work. Vince, a Recycling First volunteer, commented on the monotony of the task (tying together plastic bags), observing that people in "real life" only accept such work when given no other alternatives, "It seems to me that I am part of a factory production line now... doing such mechanical work has to be considered as a means to an end, when you need cash for paying the bills." Here, the standardization and the "factory production line" aspect of work invokes a monetary incentive ("paying the bills"), decoupled from meaningfulness. The fieldworker, additionally, noted a similar work experience while volunteering as a bartender for Baristas in a trendy refashioned red bus. Space in the bus was narrow and volunteers spent several hours working under pressure.

Figure 1 about here

"Our task entailed little variation: we had to prepare glasses and drinks with an allocated number of fruits inside (2 slices of strawberries, 1 slice of cucumber, 1 slice of orange) and put them all in the fridge before serving. During the busiest time of the day, the Pimms' bar was selling this drink nonstop and we resembled a production line."

While creating standardized processes was instrumental to servicing a busy festival, the extreme nature of the standardization (exact numbers of ice cubes or fruit slices) created a sense of mass production aligned with increasing turnaround rather than meaningful service interactions.

Team organizers were aware of the standardized aspect of the work, and while they often used a rhetoric of togetherness and solidarity, they admitted in interviews that the operation was largely commercial. The Chair for the Bars for Equality political committee (charged with "mobilizing trade unions, 
charities and campaign groups to supply labour"), who had been in the festival business since 1985, noted the commercial turn of the festival's business:

"So there's a deal there, but in the end I think we're very clear that it is a business. You know the outdoor music festival is a business, there's nothing particularly political about putting bands on in a field, and young people coming to watch it, in our view."

Related to the view of work as a commodity to be extracted, volunteers often complained of an overemphasis on productivity, secured through invasive monitoring mechanisms. As a bar server recounted to the fieldworker, even short cigarette breaks were policed and associated with guilt and mistrust.

Formalized monitoring mechanisms, such as cameras, were present throughout the volunteer space. The fieldworker was not aware of these until a volunteer pointed out that all work was being monitored on camera without her being aware. In the past, volunteers had allegedly been caught stealing money, making such protective measures apparently necessary. As noted in the field notes:

"As I learned, Bars for Equality through time became more and more careful of the issue of volunteer control, especially when volunteers dealt with operations at the tills. Each bar actually has a number of cameras able to check if volunteers steal money from the tills and if drinks are given away to people for free."

This tightening of control over workers was demotivating for workers, stirring up tensions between managers and volunteers. As Luke, a team leader, explained after a long night shift, the formerly free and informal festivals of the past had given way to more controlled commercial operations:

"Things have changed through time and now it is difficult to find people that want to come and raise money. The problem is that we used to be in a very informal environment, but now they are more alert with what we do when we work, the breaks that we take and all what is around it."

In short, the festival setting did not seem to obviate classical struggles over work control, standardization and surveillance (Braverman, 1974).

\section{Volunteer Work as Tedium and Drudgery}

Given the commodification and control surrounding the tasks, it is not surprising that members often described tasks in unflattering terms. Despite the lofty promises in promotional materials, daily tasks were mundane (collecting trash, pouring drinks or organizing materials, see Figure 2). A fellow volunteer for Recycling First, Tim, was disappointed to discover that the reality of the job departed from his expectations, with few specific skills needed and a lack of debate across the group on environmental issues.

"I think that, as volunteers, we are not really aware of what the role is going to be like. On the website it is not clear at all and you think that you're going to do some incredible activity while then you are just litter picking."

The repetitive nature of the work was exacerbated by the standardization of tasks, the surveillance and the perception of the activities as being externally-controlled. 
Low-skilled tasks were considered a necessary evil by organizers, who added that volunteers could enjoy the festival after work. Yet the drudgery of tasks let to fatigue and was experienced through the lens of economic instrumentality by workers: "We had to break the rules and hide in an indoor space to recover from the fatigue and avoid losing the deposit" (Tim).

Despite formalized arrangements about work shifts and breaks, volunteers often worked around those arrangements. The drudgery and the need for clandestine workarounds was reinforced by the status inferiority of not being a "real" worker, in contrast to those on formal contracts. Jane, a Baristas volunteer, had been unaware and was surprised to not the presence of paid workers who were given specialised activities (e.g. cocktail bars, bar supervisors); she expressed her sense of exclusion at being relegated to the more menial tasks: "It's so miserable that they [the organisers] also stress that we are different from paid staff"'.

\section{Work as the Price of Play}

In the commodity frame, volunteering was contrasted with the consumption experience of the festival, with work being the price paid for attending the festival. The festival space, framed as one of commercial transaction, was thus divided into the monotonous sphere of production versus the gratifying consumption area outside of work.

From the organizers' side, the work model of volunteering drew on the promise of enjoyment. Liz, a Chief of Sustainability Officer, reported candidly: "The deal is very clear for volunteers- they have to work 6-hour shifts and have the rest of the time to enjoy the festival. I think this is a very fair deal." Describing the "fair deal", Liz emphasized the transactional nature of volunteering, and the terms of the transaction (number of shifts, camping, hot showers and staff catering). Team organizers emphasized that volunteer access provided a "better experience" than paying for entry, but this experience was linked to individual amenities (e.g. hot showers), rather than social or collective solidarity.

In general, there was a sense of relief after shifts for volunteers, and an excitement about the night's festivities; counting down time was common practice. Counting down helped pass the time, but also symbolically demarcated the work-consumption boundary, a temporal boundary whose crossing was also marked by the highly-ritualized redeeming of free drink tickets at the end of the countdown (see Figure 3).

Figure 3 about Here 
In summary, the commodity framing recast volunteering as an economic activity where control, standardization and surveillance assured compliance, while opportunities for meaningfulness were relegated to the post-work consumption sphere, the entry to which was earned upon successful completion of work.

\section{Work as Communitas: Elevating Drudgery through Service and Solidarity}

While the commodity frame paints a picture of volunteering as monotonous and boring, we found in parallel a very different experience, reported by both organizers and volunteers across our sample. In contrast to tedium, many volunteers reported meaningfulness and gratification in their work, reminiscent of current meaningful work perspectives (Lips-Wiersma \& Morris, 2009), and evoking a sense of communitas. If the commodification frame echoes Budd's (2011) notion of disutility, this conception was more akin to work as a social relation, with an emphasis on interpersonal bonds. Making friends and spending time together on the site was commonly recognised as crucial to the volunteer experience, including during working hours. Many volunteers were introduced to the festival through friends and social connections. Importantly, such experiences were not purely consumption-related, but conditioned the work experience itself: "We are all allocated to the same shifts and we always work together. So behind the bar, you can laugh with the rest of the group while you are serving" (Gemma, volunteer for Bars for Equality). Gemma, an inexperienced volunteer, was adopted by her group as a new member; as she recounts, a sense of coalescence developed when volunteers worked together over a shift. Laughing and joking promoted a sense of belonging and built common experiences.

Volunteers expected that their fellow workers would support them during the operations, and work was considered meaningful when solidarity and togetherness were linked to tasks. For example, at the organization Bars for Equality, volunteering meant accompanying the team for the duration of the festival.

"I can take care of you, no worries...you don't have to do much and if you see that you're struggling for something, no hesitation! There is no pressure when you serve and we are working all together on the same side of the bar. So we can help each other and take breaks if we feel too tired" (Mike, older volunteer, Bars for Equality).

In stark contrast to the assembly-line view of bar work, alienation gave way to a supportive, communitarian spirit, with experienced volunteers reassuring newcomers; as compared to the suspicion, surveillance and control associated with the former view, the latter embodied trust and mutual support. This sense of togetherness carried over to non-working hours but, rather than the previously-describe focus on consumption, non-work togetherness was seen as a ritual consolidation of communal living, for instance, in the habit of gathering around a communal bonfire at night or under a common tent (Figure 4).

Figure 4 about Here 
The end of the daily festival concerts revealed a world hidden to the festivalgoers' eyes, where groups of volunteers convened around a fire or tent and spoke about their shifts and the festival line-up (i.e. work and enjoyment mingled together). Gemma felt that this moment constituted the height of her volunteer experience, "This is what I enjoy most from festivals, the sense of warmth coming from the fire and you know that everyone is so friendly with you and talking with people has never been so easy”. The communitarian aspect of the festival experience contrasts enigmatically with the commodification described previously. While both commodity and communitas framings emphasized the end-of-shift moment, this moment is symbolically marked in different ways. While ritualistic collective celebration characterizes both, the exchange of drink tickets in the former contrasts with the collective presence of the latter, associated with music and conversation, and the collective "buzz" of discussing the musical line-up for the evening.

\section{Work as Liminality and Communitas}

Volunteers and organizers frequently framed work as bringing people together and creating community through personal relationships. The sense of being in a space apart from everyday life, a different kind of place, framed a liminal space supporting informal relational bonds. By considering work through the lens of liminality, volunteers and organizers brought work into the festival space, thereby eroding the sense of work as a necessary sacrifice for consumption ends. As Gemma explains:

"You know, I work as a bartender in a bar in Brighton and I know how boring and exhausting the work can be. Since this is my work, it could seem crazy that I also come here to serve. But you know, when I'm here I feel relaxed. Festivals are like that, no-one will assess your performance and you can stay with your friends and space your work out with fun. Yes, I have fun. Here, my friends are at the heart of it!" (Gemma, volunteer for Bars for Equality)

The personal commitment of volunteers further contrasts the frames of communitas and commodity. The "special" atmosphere elevates tasks normally considered to be tedious; mundane practices take on an aura of meaningfulness, and material fatigue is dismissed as belonging to a different sphere, nuancing the otherwise alienating aspect of work.

When work was framed as communitas, working together successfully was regarded as a source of value and meaningfulness, a contribution to a collective process. Rachel, an active member of Recycling First, felt that voluntary activity was meaningful because it enacted a sense of community and set an example of identification among festival goers:

"I know that you end up very tired when you are about to finish the shift. But we need to be accurate precisely in this phase. We represent an important contact point with festival goers and we need to give the right example on how to recycle. At the end they follow our instructions and if we show that we're bored by our task they will perceive that what we are doing is not valuable."

Rachel emphasizes the value of the activity, not in economic terms, but in terms of social assistance.

Importantly, "performance" here refers to social performance ("we need to give the right example"), as if it were ritualized, rather than solely economic performance associated with exchange. In the social 
performance of work, dedication to the point of exhaustion establishes the communal value of the activity. The "contact point", is simultaneously a point of communion with the festival goers, a point of being exemplary and a point where work becomes valued. We may sense here the union of communitas and liminality (Turner, 1969) marking symbolic action as both communal and meaningful.

The temporary and transitory working context made the festival particularly suitable to experimentation within this liminal, provisional space. As Rachel comments:

"I have just finished my Bachelor's and I see myself in a kind of transitory moment now where I am trying to figure out what to do. I went to a festival because I wanted to take a break before deciding what to do...In fact, I am so happy to know new people and to make friends. You know I am so uncertain about my future and what I will be."

Being a volunteer here describes a liminal condition. Volunteers experiment with provisional moments and search for meaningful experiences with others. Liminality suspends the economic expectations of work transactions, re-focusing on social connections in a moment of personal change and building a community out of a provisional space. This community, expressed through labouring together, takes on a deeply meaningful sense, and even at times takes a quasi-transcendental tone: "So, gathering people together, pitching a tent, knowing people next to you, is our way to take the energy: the energy that we are not going to take from the sun! Festivals are all about this" (Jack, catering volunteer).

\section{Communitas as Meaningfulness within the Festival Work Experience}

Framing volunteer work as communitas, as described above, led mundane tasks to be transformed into meaningful communal experiences. Rather than being solely transactional or commercial, volunteers perceived work as meaningful when it involved a community role within the festival.

Anna, a not-for-profit organization manager at Stewards against Unfairness, explained how volunteers were valued because of their commitment to the group, rather than for their cheap labour: "You know, we don't use volunteers because they're cheap. We use volunteers because they're dedicated and committed, interested: it's the responsible thing to do". Such statements seem to be in contrast with the commodification view of volunteering, yet sit in ambiguous relation to Anna's own previous comment above regarding the transactional aspect of volunteering; the "interest" referred to seems to be of differing orders across the interviews, at one moment constituting interest in a free ticket, while at others interest in the cause, the moment of the festival, or the group, further highlighting the heterogeneity of momentary experiences of the work.

Within the temporary space created by the festival, work practices are imagined as supporting community and a personal connection to the group. As Andy, a friend of the Recycling First owner, explains (see Figure 5): 
"Actually, the reason I am here is because I want to help Elaine to run all this smoothly. So I took the task of arranging the kitchen and cooking for the ones who want to hang around under this tent after their shift. We are first of all a community of people who enjoy staying together, chat, smoke and have a drink."

Figure 5 about Here

Andy equates participation with a sense of togetherness, without economic considerations. He is often involved in mundane activities such as food service operations or cleaning work stations, and seems gratified by the opportunity to cooperate with others.

The sense of communitas, while linked to festivity, was not exhausted by the consumption experience, and members often distinguished between consumption-related and communitarian togetherness, as the latter involves deep relationships between members, linked to wider social missions:

"People should be more sensitized about what we do as volunteers. Yes, at festivals you have fun but I hate to work with people that are drunk. They should understand that first we are here for a charity that is collecting money from our work and they are doing that for good. We need to be dedicated during our shift; hangovers should be left at home (Edward, volunteer on-site for a charity)"

For this team member, the act of "doing good" is accentuated by the choice of volunteering for charity and contrasted with a devalued approach of experiencing the festival as a mere consumption experience,

epitomised by "getting drunk". Instead, work is understood as involving solidarity and community, invoked by a pastoral "village" metaphor. Penelope, a volunteer for Bars for Equality, expressed this by referring to the common living space and temporary community established by members:

"It has been a while now that I worked at festivals and I like the sense of community that you create during your shift, and that is strengthened when you hang out with people afterwards. By spending long hours with the same people and by camping on the staff campsite, you end up having neighbours and you say hello to people around you...so it becomes a village and you cry on Monday when you have to leave the festival."

This sense of relation with physically-close others evokes, at times, wider social and political messages that, despite their distal nature, are made sensuous by their linkage with the situated relations. As Anna, from Steward against Unfairness, notes: "People [volunteers] like to feel part of something. They like to feel that sense of making a change to the festival as well as to the world."

The senses of continuity and community on the one hand, and transformational change on the other, seem paradoxically related; indeed, Turner (1969) formulates communitas specifically to account for this apparent paradox between stability and liminality. The liminal relation links self and other, present and past, and unfreezes the status quo so as to facilitate radical thinking:

"I like so much the fact that here you can listen to the glorious bands of the '60. I used to go to festivals when I was a young rebel and I love the fact that at those festivals revolutions took place and you went there to fight for your rights"'(Andy, friend of Recycling First owner).

\section{Communitas as Ideology: Exploitation and Counter-Exploitation}


Thus far, we have described a contrast between the commodification of volunteer work on the one hand, and the sense of communitas on the other. Reframing work as communitas constitutes a powerful incentive for managers to valorise volunteering without raising costs, while for employees it adds legitimacy and dignity to tasks that may otherwise seem menial or useless. As such, communitas not only serves to resignify work around community, but it acts as a powerful ideological force that, when harnessed discursively, allowed actors to legitimize their social and economic practices. Communitas as a discourse is used strategically to ideologically reframe work and, although for different reasons, this ideological move unites, rather than divides, workers and organizers within a common narrative of meaningful work.

\section{Communitas Rhetoric Supporting Free Labour}

Some managers explicitly referenced the transactional, business-like nature of work, focusing on getting work done efficiently (i.e. “a day’s pay for a day’s work”), to counter the idea that everyone was there solely for fun. As above, the "fun" frame forms the counterpoint to work. By contrast, the ideological use of communitas de-emphasizes fun and stresses togetherness, mutual gratification and social value. When framed as community rather than consumption, managers can exert normative pressure without producing a sense of alienation among volunteers. The rhetoric of communitas not only re-signifies work; it also gives managers a strong lever with which to increase productivity.

During a conversation with the Chair of the Bars for Equality political committee, it emerged that allocating volunteers alongside their friends could increase on-site work efficiency. Besides cutting costs by effectively outsourcing training, mutual support allows volunteers to sidestep situations of conflict with customers and boost motivation:

"You see, this is the point. We had small groups of six people who knew each other, they're not gonna let their friends down; that's the point, that's what works for us. So in terms of the details of how we manage, when we put people in our bars...As far as possible, they know each other and have a relationship with each other. And when we do that, it works."

Manipulating community feelings allows festival organisers to cut costs in training volunteers while maintaining neo-normative, informal control. Anna, a festival team manager, noted how this sense of community can promote a long-term commitment to the festival, despite the lack of economic remuneration:

"We have people who have been coming with us for years. They have come perhaps when they were students, they leave when they get their first job, they get married, they have their family, they return to us when they're older. You know, we have volunteers who worked in the field for us for years who are too tired to work in the field now but they can do office work instead and help us with office jobs" (Anna, Festival Team Manager-Stewards Against Unfairness).

The ideological use of communitas to encourage voluntary work is shown through concrete behaviours in the field. To valorise work, volunteers, team managers and supervisors would spur on the team using a commitment-based rhetoric aimed at motivating volunteers. As noted in the field notes: 
"Self-reinforcing words about the greatness of our team of volunteers play an important part in building a sense of group. During all of my experiences as a volunteer, I noticed that quite often team leaders as well as volunteer members use a range of words to express how good we are as team."

Despite this affirming language, the ambivalence of the work and the sense of being treated differently from paid staff was manifest in a few episodes where volunteers noticed gaps between discourse and reality, unearthing a bedrock of exploitation beneath the discourse of community. During one late night shift, two friends became upset when asked to prepare the bar station for the next day, a cleaning job supposedly outside their scope, as well as occurring after their allocated shift time:

"Sylvia: Excuse me, what do you mean? The shift finished at 2 am and now it is 2:10 in the morningto be honest I'd like to go home.

Supervisor: Well, with a little help from everyone, we will all go home sooner!

Sylvia: I'd like to sign out now, please.

Erica: Yes, I'll do the same-I don't want to work anymore.

Supervisor: All right girls, but I will note your names and this can have an effect on your deposit."

This conversation, noted during the researchers' volunteer work at the drinks bar, shows the double-sided or ideological use of communitas discourse. While at the beginning, the supervisor evokes a sort of collectivist spirit ("with a little help from everyone"), as the conversation becomes tougher, the material underbelly of the transaction becomes apparent as she turns to a coercive recourse. While the deposit is claimed to be a guarantee that volunteers show up for the shifts, in this instance the device is used coercively as a lever for compliance within work.

\section{Counter-rhetoric: Community as a Pretext for Party Favours}

While managers used communitas discourse as ideology to mask productivity goals, volunteers were themselves frequently complicit with ideological uses of communitas in a different sense. Speaking about togetherness and solidarity allowed participants to transform monotonous tasks into enjoyable activities with peers. At other times, this allowed them to assert control over how and with whom they worked. More cynically, however, workers could gain free access and valuable insider status at the festivals, while managers could leverage social ties as a form of control. The diverse uses of communitas discursively aligned volunteers with organizers, despite differences in material or economic interests among the groups. Lucy, a musician who volunteers for Bars for Equality, notes that she "like[s] the atmosphere at festivals", linking it to her musical interest, but also that "It's a good way to have free access, as this is too expensive for me otherwise." From the perspective of the managers, however, the focus on meaningful connection to others served a useful disciplinary purpose:

'So that's how we try and do it, because that's just human nature-you'd let down a huge organisation, but you're not going to let down your friend that you might have to go to a branch meeting with next week. It's basic psychology isn't it? But it works very well, and it's the socialist discipline of those organisations that carries us through" (Chair of the Bars for Equality political committee). 
The reference to "socialist discipline" is remarkable considering the unpaid labour, the consumptionrelated spectacular nature of the event and the explicit admission immediately prior that it is "human nature" to "let down a huge organization". Yet it is precisely this juxtaposition of plural explanations that seems to signal the rhetorical use of communitas as a pretext for some other motive.

Volunteering facilitated access, and the line between consuming with friends and engaging in community building was not always clear. Some members spoke of a "corruption" of the festival ethic, as if the latter had been co-opted or diminished. As one veteran remembers:

"What we found over the years, it's much more likely now that the people who come volunteer for us, are predominantly there as a way of getting into the festival. It wasn't so much the case 10 years or 15 years ago... all the surveys we've done recently: their main priority is access to the festival, especially to Glastonbury, because Glastonbury is such an iconic festival. And we have a problem - in recent years that is - a problem with trying to pick through people's motivations... And that's a good indicator of the fact that in the mid-80s and 90s, I think, when the political landscape was much more lively, there were much more committed people."

This manager was aware that, for some volunteers, not paying the full cost was an important incentive.

"Getting in" meant occupying a special space (behind the scenes, in a staff safety area), which was experienced as a premium consumption experience rather than a communal experience. The Bars for Equality committee member, reflecting on the festival community atmosphere, saw this as a naïve supposition, dismissing the purported communitas and its political potential, as a cover-story:

"I think you find that people, most customers at most events... people see themselves as a consumer of a product, they don't see themselves as attending or participating in a festival. I think that's absolutely the key....If you're trying to engage somebody who considers themselves a consumer of a product in politics, they look at you like, 'What are you talking about?' They don't-at most festivals - they don't feel any solidarity with each other. They don't feel that they're there having a shared experience as a festival participant. They're there as consumers."

Despite this more cynical interpretation of volunteers' motivations, many respondents did cite political or social credentials. If communal space was instrumental, members also framed their actions in solidaristic terms - even when such a framing was not, strictly speaking, necessary for free entrance. In many cases, volunteers seemed driven by the opportunity to reinforce their social status, for example, through networking.

Billy, a volunteer interested in a trade union career, saw the political side of the festival as an entry point to meeting more senior political actors:

"You know, I'd like to get in touch with trade unionists of Bars for Equality and I think that festivals can be a great place for doing that. Yesterday night after the shift I went to the communal area and I met a couple of guys who have been involved in the unions. It was easy to speak with them because of the informal atmosphere, while in different contexts I could not even imagine having a formal chat with them."

The personal commitment is here linked to an opportunity to get to know the right people, and is instrumental to enhancing a career path, a blend of social and instrumental motives. Although not directly economic, Billy's statement notes the instrumentalization of communitas ("it was easy to speak with them 
because of the informal atmosphere"). This use of the atmosphere for professional advantage was common, as noted in the field notes:

"During some conversations, I realised that volunteering is a good way to enhance the CV. Using volunteering experience in job applications and interviews is quite common among young people. Volunteers choose often to volunteer with renowned charities and especially people who envision applying for universities tend to choose charities to enrich their $C V$."

In summary, we noted moments where festival work seemed neither purely instrumental nor communal and idealistic, but instrumentally conscientious, using the social and cultural capital of the festival to achieve goals that, while not immediately material, were instrumental. Such cases blurred the distinction between idealistic and instrumental action, affirming social goals while undermining the idea of an underlying festival communitas.

\section{Discussion: Theorizing Meaningfulness within Liminal Settings}

As discussed above, meaningfulness in festival work is subject to pluralistic frames, based on the different ways that community and work are experience. To summarize these positions, we contrast frames of commodity, communitas and ideology (See Table 3).

Table 3 about Here

Within the commodity frame, labour and meaningful experience were considered separate autonomous spheres, and their relation was one of exchange. In their separation, each sphere takes on a unique appearance, with work appearing as drudgery and monotony, and meaningfulness appearing as fun and consumption. The relation between the two is a matter of compensation; one earned the credit to enjoy oneself through the payment of labour.

In the second frame, that of communitas as value, the work/fun distinction is blurred, and work is experienced as meaningful and enjoyable in itself, in its social aspect (cf. Lips-Wiersma \& Morris 2009). Focusing on communitas, individuals can be seen relationally, and the isolation of work and consumption are replaced by a collective sensibility taking place in a liminal space. Exchange notions are replaced by symbols of harmony, replete with aesthetic and social supports such as fireside songs, reminiscences of past and future dreams and the rejection of empty consumption ("hangovers should be left at home").

In the third ideological frame, the tensions within meaningful work around normative control (Mitra \& Buzzenell 2017; Bailey et al, 2016) are most evident. In this frame, work relates to meaningfulness, though not as a unity, but in an instrumentalized form, hiding the economic realities of festival work. Participants deployed a rhetoric of meaningfulness in diverse ways, with organizers emphasizing communitas to promote performance, and volunteers instrumentalising work as a cover for free concert entry. Viewed in this more cynical frame, organizers and volunteers collude in communitas discourse as a 
legitimizing narrative for self-interested goals. As such, while the commodity and communitas frames oppose each other, the ideological frame reflexively turns on this opposition, deploying the discourse of the second, while maintaining the social relation of the first. In this frame, the work is described as (and perhaps experienced as) meaningful, but the meaningfulness plays an ideological role of hiding instrumentalization.

As noted above, each frame is analytically separate from the other; yet their relation may be theorized as different forms of reflexivity around the festival experience. By individualizing meaningful experience and reducing it to the after-work consumption experience, the first frame sets up an exchange logic; conversely, in the communitas frame, boundaries are blurred between individual and collective and between work and non-work. Finally, the ideology frame holds together communitas and exchange, but regards their relationship cynically as one of ideological masking. We provide a visual sketch of these positions in Figure 6.

Figure 6 about Here

In Figure 6, the circles representing work and meaningfulness are related to and potentially conflate with each other. In the first frame, the two spheres are separate but related through mutual exchange, emphasizing equitable trade-offs between work and meaningful experience. In the second frame, the distinction itself is progressively negated, re-signifying the terms as co-extensive, in a relation of unity rather than exchange. In the third frame, the plane of comparison itself becomes differentiated, where meaningfulness "masks" work, which is obscured, and appears sporadically in candid confessions ("It's basic psychology...but it works very well"), moments of resistance (e.g. "to be honest I'd like to go home") and on-the-ground dilemmas among members (i.e. "A problem with trying to pick through people's motivations").

\section{Contributions}

By exploring the divergent aspects of experiencing meaningfulness in volunteer work, the current study contributes to our understanding of meaningful work in transient, liminal contexts, focusing on a unique setting where exchange and communitas wage ideological and discursive battles to frame festival work. The liminality of the festival space supports the production and expression of communitas. However, the instrumental use of unpaid workers for economic benefit, and their own instrumental uses of volunteerism to gain coveted festival access, creates a persistent shadow of cynicism, leading to the array of different work frames described above. Meaningful work, through each of these lenses, takes on a different aspect in its human and social implications. 
In a complex mixture of normative pressure, contractual ambiguity and the patina of social responsibility characterizing unpaid festival work, underscored by an ambience of enjoyment, our study resonates with an emerging literature around the tensions within meaningful work (Mitra \& Buzzenell, 2017; Mitra \& Fyke, 2017) and more generally, the ambivalence of “enchanting” or "fun" workplaces (e.g. Endrissat et al, 2015; Jenkins \& Delbridge, 2013; Fleming \& Sturdy, 2011). This literature highlights the dual status of workplaces that showcase their concern for workers' well-being, communitas and humanistic values, but also may contain elements of neo-normative control (e.g. Fleming \& Study, 2011). The current study adds to this discussion by noting that, beyond personal autonomy and "fun", the sense of communitas can be recruited into the neo-normative process, and is linked to the liminality of spaces set apart ritualistically as exceptions to everyday life.

Given the multifaceted nature of volunteering, it is unsurprising that reactions to work vary from an enthusiastic, almost transcendental connection, to a nostalgic yearning for a "better time" (cf. Cohen, 1985) of authentic, non-commercialized activism, to the resigned cynicism of feigning work for a free drink and a concert ticket. What is more surprising is how this plurality persists with a relative absence of social tension among members. Such eclecticism between ideological buy-in and cynicism seems odd, given the seeming contradiction between positions, and suggests that multiple reflexive positions, from ideological adhesion (e.g. Johnston, 2008) to cynicism and irony (e.g. Kunda, 1992), co-exist among members bound together in moments of intense experience (Goulding et al., 2002). The pluralistic co-existence of different reflexive positions suggests that members must position themselves among the multiple possibilities within the liminal space, echoing Ekman's (2014) argument about the heterogeneity of flexible work, but adding that liminality, by virtue of its openness, provides an ideal space in which ideological ambivalence can continue unresolved.

Our focus on multiple positions within a unique work space contributes to discussions around meaningful work, community and consumption in "alternative" organizational spaces. First, we illustrate how new work forms invoke meaningfulness beyond traditional economic incentives, while not excluding instrumental motives. Second, by linking voluntarism with the temporary nature of festivals, we contribute to understanding how such events shape meaningfulness. Third, by linking meaningfulness to ongoing debates around neo-normative control, we contribute to discussions around worker control, domination and emancipation, acknowledging that communitas can be managed and perhaps co-opted, whilst also acknowledging the micro-emancipatory moments that emerge in the festival. Below, we describe these interrelated contributions. 
The focus on meaningful work through communitas, matched with the ideological use of communitas, resonates with recent calls in the meaningful work literature to explore the ambivalent aspects of meaningful work (Bailey et al, 2016). In our setting, some workers and organizers framed activities in economic terms and dismissed communitarian ideals as naïve. Furthermore, when members did invoke meaningfulness or values, these were often used cynically by both organizers and workers, begging the question as to whether members took professed communitas seriously. That said, a very real sense of camaraderie and personal closeness was palpable in the field, and bonds were created that seemed difficult to cynically dismiss as ideological mystification. Research dating back to Roy's (1959) "Banana Time" documents the importance of informal interaction in the labour process, and how monotony and alienation are avoided through common activities and rituals (e.g. Thompson, 2003). Nevertheless, the co-occurrence of cynical and authentic community dynamics complicates such literature by suggesting that instrumental and selfless micro-moments interpenetrate during work in diverse and often contradictory ways. Questions of where, when and how these frames are deployed at work form a research agenda around the tensions of meaningful work.

\section{Liminality and the Uses (and Abuses) of Communitas}

The significance of festival work is related to the temporary and demarcated space of the festival, which frames a specific event around which meanings can be attributed. The festival is thus positioned as semi-removed from everyday life, constructing a space for a nostalgic unity that is central to the construction of community (Cohen, 1985). Thus, beyond the literature on festivals per se (e.g. Johansson \& Toraldo, 2015; Chen, 2009), the site informs emergent organizational theorizing around space and symbolic events such as rituals (e.g. Shortt, 2015; Islam, 2015) in their relation to the meaningfulness of work. Specifically, spaces become symbolically marked to give meanings to action and to permit or restrain certain activities (Shortt, 2015). The creation of spatial and temporal "events", symbolically differentiated from the everyday, allows symbolic inversions and the remaking of social norms though liminality (Islam, 2015). Liminality, however, also creates and maintains dominant orders through the normative force of communitas, downplaying conflicting group interests in everyday life. The liminal space of the event, linked to communitas, mobilizes the sense of solidarity and emotional unity within a ritualized event, but is a double-edged sword: it legitimizes processes of commodification and control, just as it gestures to a nostalgic space of extra-economic togetherness.

What our study adds to this literature by joining the notion of liminality with meaningful work, is to show how liminality supports the meaningfulness of communitas, while simultaneously buttressing potentially exploitative work arrangements. Previous studies have regarded liminality as the "in-between" of 
work practices (e.g. Czarniawska \& Mazza, 2003), of organizational change (Howard-Grenville et al, 2011), or of capitalism more broadly (Johnsen \& Sorenson, 2014), and some scholars have emphasized its role in coping with domination (Shortt, 2015). Yet the connection between liminality and meaningfulness remains obscure, given that the liminality-communitas link, as originally emphasized by Turner (1969), rarely appears in current literature.

In our site, the festival's liminal, exceptional status is key to volunteers' work experience. Liminality supports participation, re-signifies work as a form of sociality and provides a legitimating discourse for the frequently poor working conditions. Perhaps for that very reason, communitas is useful for the functioning of the festival as an economic entity, reducing labour costs while promoting a group spirit. While liminality works by alternating between social stability and change (Islam, 2015), few studies have examined the diverse uses of liminality as a managerial tool, nor its relation to meaningful work. Future research might usefully examine more deeply how such uses co-exist; our study supports such research by showing how liminal spaces reinfuse work with a sense of provisional meaning, which can then feed back into the productive apparatus.

\section{Ideology, Post-ideology and Neo-normative Control}

Our explorations of festival work are aligned with neo-normative control perspectives around new forms of work, analyzing how subjective pleasure and self-expression drive work and personal sacrifice for the organization, reducing resistance to organizational imperatives (e.g. Bunderson \& Thompson, 2009). Organizational scholars contrast conventional control mechanisms based on standardization and de-skilling (Braverman, 1974) with new forms invoking authenticity, self-expression and identification (Fleming \& Sturdy, 2011; Fleming, 2009; Anteby, 2008). These new forms of control deploy affective (e.g. Hochschild, 2011), aesthetic (Warhurst \& Nickson, 2009) and artistic (Endrissat et al, 2015) tools to frame work as constituting more than economic exchange, cynically leveraging notions of worker well-being so as to improve organizational performance (cf. Cederstrom \& Spicer, 2015; Fleming, 2009). Indeed, since classical works such as Kunda's (1992) ethnography of tech culture, the ambivalence of meaningfulness as a form of control has been recognized, with more recent surveys noting this control aspect throughout the meaningful work literature (Bailey et al 2016).

In Kunda's (1992) early work, collective culture was leveraged for employee control, while more recent neo-normative approaches (e.g. Fleming \& Sturdy, 2011) emphasize the instrumentalization of individual self-expression and pleasure. The current site is unique in that it relies on a sense of collective relationality, yet paradoxically does so outside of any established collectivity or organization; rather, the very outside-ness of the group from "normal" life creates the liminal sense that produces communitas. 
Cohesive solidarity is replaced by moments of ephemeral collective enjoyment. Framing communitas as part of the festival work experience reveals its ambivalence within the production-consumption distinction,

making it difficult to discern between what is work and what is play.

At our site, communitas was both felt by participants and was used instrumentally by all sides, motivating work practices or legitimizing consumer enjoyment. Where the idealistic and sometimes cosmic language framing festival work as a meaningful collective experience may have sounded naïve in the cynical spaces of everyday life, in the rarefied atmosphere of the festival these sentiments could operate free of the obstacles of cynicism. Yet, as our third category shows, individuals are aware of and use this difference with guile; they did not leave cynicism at the gates. They often switched between registers of communitas and cynicism, deploying their sense of solidarity with caution and, when pushed, they were ready to push back with the refrain of "It's just a job; we're just here for fun". In this context, meaningfulness is valued, but its value shifts - from a payoff after work is over, to an intrinsic aspect of work, to a discursive strategy to give a cloak of legitimacy to the festival environment.

\section{Limitations and Future Directions}

Despite the above contributions, questions remain regarding the relationships between festival events, communitas and the nature of work. First, Turner's (1969) discussion of liminality focuses on the communitas as the duality between "structure" and "anti-structure", producing tensions between control and expression, as we noted in our data. Turner (1969) briefly refers to modern settings (in his discussion of "hippies", for instance) as containing liminality and communitas, but largely focuses on ritual settings in which social norms are totalizing and symbolically uncontested. The variety we observe may have to do with the more pluralistic and diverse aspects of liminality in modern society (Johnsen \& Sorenson, 2014); thus, how liminality and communitas work differently across diverse work spaces and types, including "normal" organizations, remains an important issue to address. In our site, the heterogeneity and temporariness of contemporary festivals may mark them as "quasi-rituals", achieving pockets of liminality and communitas with mixed success in detaching symbolic reality from the everyday. Such quasi-rituals, where communitas co-exists with the mundane, require further exploration (cf. Johnsen \& Sorenson, 2014; Esposito, 2013), as they are likely to reconfigure liminal spaces and symbolic meanings in diverse ways.

Thus, further investigation beyond the current site can help to understand the different contours of liminality in work settings more generally.

Second, because we focused on the micro-dynamics of work experiences within the festival, we did not foreground the social and economic relationships supporting the festival and its communities. Before the festival, volunteers had been coordinated by their respective organizing groups, and previously through fan 
clubs and musical communities. The relation between these communities and the productive apparatus of festivals requires further exploration, existing as it does at the intersection of cultural consumption and flexible work.

Third, these macro communities are themselves embedded in larger class, ethnic and national imaginaries left largely aside in our exploration, which is a clear limitation of the current approach. Discourses around race, gender and social class, for example, were largely absent from our interviews, giving us limited material at the micro level; this does not mean that such discourses did not appear or that their effects were absent. The choice of bands and the relatively high cost of entry, for example, may have created subjective and objective barriers to entry for certain groups. Clearly, the feeling of universal togetherness embodied in communitas in no way implies universal inclusion in fact. The way that communitas within the festival coexists with objective exclusions and social distinctions is an important layer to add to the story of festival enchantment.

To end with a broader speculation, our work on festivals resonates with a growing domain of workplace phenomena, where the stakes of meaningfulness and self-expression are fraught with ambivalences. As in other cases, tensions lie at the crux of work and non-work, where one bleeds into the other and the direction of influence is unclear. This blurring of boundaries requires rethinking work as a category of social action. In analyzing how work meanings blur in contemporary spaces of symbolic togetherness, we hope to make inroads into the new ways in which these activities are remaking the worlds of work and meaning.

\section{References}

Aguinis, H., \& Glavas, A.(2017). 'On corporate social responsibility, sensemaking, and the search for meaningfulness through work'. Journal of Management, onlinefirst.

Anteby, M.(2008). 'Identity incentives as an engaging form of control: Revisiting eniencies in an aeronautic plant'. Organization Science, 19, 202-220.

Bachman, J.R., Backman, K.F., \& Norman, W.C.(2014). 'A segmentation of volunteers at the 2013 Austin City Limits Music Festival: Insights and future directions'. Journal of Convention \& Event Tourism, 15, 298-315.

Bailey, C., Madden, A., Alfes, K., Shantz, A., and Soane, E. (2016) 'The mis-managed soul: Existential labor and the erosion of meaningful work'. Human Resource Management Review, 27, 416-430.

Bailey, C., \& Madden, A. (2017). 'Time reclaimed: Temporality and the experience of meaningful work'. Work, Employment and Society, 31, 3-18. 
Bailey, C. \& Madden, A. (2016). 'What makes work meaningful - or meaningless'. MIT

Sloan Management Review, 57, issn 1532-9194

Bakhtin, M.(1984). Rabelais and his World. Bloomington, IN: Indiana University Press.

Barron, P. and Rihova, I. (2011). 'Motivation to volunteer: a case study of the Edinburgh International Magic Festival'. International Journal of Event and Festival Management, 2, 202-217.

Bauman, Z. (2000). Liquid Modernity. Cambridge: Polity.

Beverungen, A., Birke, O., Spoelstra, S., Kenny, K. (2013). 'Free work'. Ephemera, 13:1-9

Brannan, M.J., Parsons, E., \& Priola, V. (2015). 'Brands at work: The search for meaning in mundane work.' Organization Studies, 36, 29-53.

Braverman, H.(1974). Labor and monopoly capital: The degradation of work in the twentieth century. London: Monthly Review Press.

Bourdieu, P.(1990). The Logic of Practice. Stanford: Stanford University Press

Budd, J.W.(2011). The Thought of Work. Ithaca, NY: Cornell University Press.

Bunderson, J.S., \& Thompson, J.A. (2009). 'The call of the wild: Zookeepers, callings, and the double-edged sword of deeplymeaningful work.' Administrative Science Quarterly, 54, 32-57.

Castillo, J.J.(1997). 'Looking for meaning of work'. Work and Occupations, 24, 413-25.

Cederstrom, C. and Spicer, A.(2015). The wellness syndrome. London: Polity.

Cederstrom C. and Fleming, P.(2012). Dead man working. London: Zero Books.

Chen, K.K. (2012). ‘Artistic prosumption: Cocreative destruction at Burning Man'. American Behavioral Scientist, 56, 570-595.

Chen, K.K.(2009). Enabling Creative Chaos. The Organization Behind the Burning Man Event. Chicago: University of Chicago Press.

Cohen, A.P.(1985). The symbolic construction of community. London: Routledge.

Czarniawska, B. \& Mazza, C.(2003). 'Consulting as a liminal space.' Human Relations, 56, 267-290.

Dale K and Burrell, G.(2008). The Spaces of Organization and the Organization of Space: Power, Identity and Materiality at Work. London: Palgrave.

Dempsey, S.E., Sanders, M.L.(2010). 'Meaningful work? Nonprofit marketization and work/life imbalance in popular autobiographies of social entrepreneurship? Organization, 17, 437-459.

DeVoe, S.E., \& Pfeffer, J.(2007). 'Hourly payment and volunteering: The effect of 
organizational practices on decisions about time use'. Academy of Management Journal, 50, 783-798.

Du Gay, P. \& Morgan, G. (Eds, 2013). New Spirits of capitalism? Crises, Justifications, and dynamics. Oxford: Oxford University Press

Ekman, S.(2012). 'Fantasies about work as limitless potential - how managers and employees seduce each other through dynamics of mutual recognition'. Human Relations, 66, 1159-1181.

Ekman, S.(2014). 'Is the high-involvement worker precarious or opportunistic? Hierarchical ambiguities in late capitalism'. Organization, 21, 141-158.

Endrissat, N., Islam, G., \& Noppeney, C.(2015). 'Enchanting work. New spirits of service work in an organic supermarket'. Organization Studies, 36, 1555-1576.

Esposito, R.(2013) Communitas: The Origin and Destiny of Community. Stanford: Standford University Press

Fineman, S.(2012). Work. A very short introduction. Oxford University Press

Fleming, P.(2009). Authenticity and the cultural politics of work: New forms of informal control. Oxford: Oxford University Press.

Fleming, P., \& Spicer, A. (2007). Contesting the corporation. Cambridge, UK: Cambridge University Press

Fleming, P. \& Sturdy, A.(2011). 'Being yourself' in the electronic sweatshop: New forms of normative control. Human Relations, 64, 177-200.

Getz, D.(2010). 'The nature and scope of festival studies'. International Journal of Event Management Research, 5, 1-47.

Gibbert, M., \& Ruigrok, W.(2010). 'The "what" and "how" of case study rigor: Three strategies based on published work' Organizational Research Methods, 13, 710-37.

Gill, R., \& Pratt, A.(2008). 'In the social factory?: Immaterial labour, precariousness and cultural work'. Theory, Culture \& Society, 25, 1-30.

Goulding, C., Shankar, A., Elliott, R.(2002). 'Working weeks, rave weekends: Identity fragmentation and the emergence of new communities'. Consumption Markets \& Culture, 5, 261-284.

Harvey, D. (2001). Spaces of Capital: Towards a Critical Geography. Routledge: NY.

Hochschild, A.(2011). 'Emotional life on the market frontier'. Annual Review of Sociology, 37, 21-33.

Howard-Grenville, J., Golden-Biddle, K., Irwin, J., \& Mao, J. (2011). 'Liminality as 
cultural process for cultural change'. Organization Science, 22, 522-539.

Isaksen, J.(2000). 'Constructing meaning despite the drudgery of repetitive work'. Journal of Humanistic Psychology, 40, 84-107.

Islam, G.(2015). 'Rituals in organizations: Rupture, repetition, and the institutional event.'

In R. Mir,

H.Willmott \& M. Greenwood (Eds.) The Routledge Companion to

Philosophy in Organization Studies. London: Routledge.

Islam, G., Zyphur, M.J., \& Boje, D.(2008). 'Carnival and spectacle in Krewe de Vieux and the Mystic Krewe of Spermes: The mingling of organization and celebration'. Organization Studies, 29, 1565-1589.

Jenkins, S., \& Delbridge, R.(2013). 'In pursuit of happiness: A sociological examination of employee identifications amongst a "happy" call-centre workforce.' Organization,

21, 867-887.

Johansson, M., \& Toraldo, M.L.(2015). 'From mosh pit to posh pit: Festival imagery in the context of the boutique festival'. Culture and Organization, 1-18.

Johnsen, C.G., Sorensen, B.(2014). 'It's capitalism on coke!: From temporary to permanent liminality in organization studies'. Culture and Organization, 1-17.

Johnston, J.(2008). 'The citizen-consumer hybrid: ideological tensions and the case of Whole Foods Market'. Theory and Society, 37, 229-270.

Kalleberg, A.L.(2009). Precarious work, insecure workers: Employment relations in transition. American Sociological Review, 74, 1-22

Kunda, G.(1992). 'Engineering Culture: Control and Commitment in a High-Tech Corporation'. Philadelphia: Temple University Press.

la Cour, A., \& Højlund, H.(2008). 'Voluntary social work as a paradox'. Acta Sociologica, $51,54-54$.

Land, C., Taylor, S.(2010). 'Surf's up: Work, life, balance and brand in a New Age capitalist organization'. Sociology, 44, 395-413.

Lips-Wiersma, M., \& Wright, S. (2012). 'Measuring the meaning of meaningful work: Development and validation of the comprehensive meaningful work scale (CMWS)'. Group and Organization Management, 37, 655-685.

Lips-Wiersma, M., Morris, L.(2009). 'Discriminating between 'meaningful work' and the 'management of meaning' Journal of Business Ethics, 88, 491-511.

Lucas, M.J.(2014). 'The organizing practices of a community festival. Journal of 
Organizational Ethnography, 3, 275-290.

Mackellar, J.(2013). 'Participant observation at events: theory, practice and potential,

International'. Journal of Event and Festival Management, 4, 56-65.

Mitra, R., \& Buzzanell, P. M. (2017). 'Communicative tensions of meaningful work: The case of sustainability practitioners'. Human Relations, 70, 594-616.

Mitra, R., \& Fyke, J. (2017). 'Purpose-driven consultancies' negotiation of organizational tensions'. Journal of Applied Communication Research, 45, 140-159.

Muirhead R (2004) Just Work. Harvard: Harvard University Press.

Neff, G., Wissinger, E., Zukin, S.(2005). 'Entrepreneurial labor among cultural producers: "cool" jobs in "hot'" industries'. Social Semiotics, 15, 307-334.

O'Toole, M., \& Grey, C. (2015). 'We can tell them to get lost, but we won't do that: Cultural control and resistance in voluntary work'. Organization Studies, 37, 55-75.

Parker, M.(2011). 'Organizing the circus. The engineering of miracles'. Organization Studies, 32, 555-569.

Petriglieri, G., Ashford, S.J., \& Wrzesniewski, A.(2018). 'Agony and ecstasy in the gig economy: Cultivating holding environments for precarious and personalized work identities.' Administrative Science Quarterly, onlinefirst

Prentice, R., \& Andersen, V.(2003). 'Festival as creative destination'. Annals of Tourism Research, 30, 7-30.

Raunig, G., Ray, G. Wuggenig, U.(2011). Critique of creativity. Precarity, subjectivity and resistance in the 'Creative Industries'. London: Mayfly.

Rose, G.(2001). Visual Methodologies: An Introduction to the Interpretation of Visual Materials. London: SAGE

Rosso, B.D. Dekas, K.H., Wrzesniewski, A.(2010). On the meaning of work: A theoretical integration and review. Research in Organizational Behavior, 30,91-127.

Roy, D.F.(1959). "Banana time”: Job satisfaction and informal interaction. Human Organization, 18, 158-168

Shershow, S. C. (2005), The Work and the Gift, London \& Chicago, The Chicago University Press. Shortt, H.(2015). 'Liminality, space and the importance of "transitory dwelling places" at work'. Human Relations, 68, 633-658.

Standing, G.(2011). The precariat. London: Bloomsbury Academic.

Sturdy, A., Schwartz, M., \& Spicer, A.(2006). Guess who's coming to dinner? Structures 
and uses of liminality in strategic management consultancy. Human Relations, 59,929-960.

Sutcliffe, S.(2003). Children of the New Age: A History of Spiritual Practices. London: Routledge.

Thompson, W.E.(2003). 'Hanging Tongues: A Sociological Encounter with the Assembly Line'. In Harper, D. and Lawson, H.M.(Ed.), The Cultural Study of Work, p. 313-34. Lanham: Rowman \& Littlefield.

Toraldo, M.L. \& Islam, G.(2017). 'Festival and Organization Studies'. Organization Studies, in press.

Turner, V.W.(1969). The Ritual Process. Chicago: Aldine.

Vallas, S., \& Prener, C.(2012). 'Dualism, job polarization, and the social construction of precarious work'. Work \& Occupations, 39(4), 331-353.

Van Gennep, A. (1909). Les rites de passage. Paris: Émile Nourry.

Warhurst, C., \& Nickson, D.(2009). 'Who's got the look?' Emotional, aesthetic and sexualized labour in interactive services'.Gender, Work, Organization, 16, 385-404.

Yeoman, R. (2014). 'Conceptualising meaningful work as a fundamental human need'. Journal of Business Ethics, 125(2), 235-251.

Yeoman R.(2014b) Meaningful Work and Workplace Democracy: A Philosophy of Work and a Politics of Meaningfulness. Basingstoke: Palgrave Macmillan. 
Table I. Data sources and their use in the analysis

\begin{tabular}{|c|c|c|}
\hline Source & Type of data & Objective in the analysis \\
\hline $\begin{array}{l}\text { Informal } \\
\text { interviews, } \\
\text { conversations } \\
\text { and field notes } \\
\text { (as noted in } \\
\text { research diary) }\end{array}$ & $\begin{array}{l}\text { Site } 2 \text { - Camp Bestival, Dorset (UK) } \\
-5 \text { unpaid volunteers, } 2 \text { station supervisors (paid } \\
\text { staff) and } 1 \text { cellar manager (paid staff), members } \\
\text { of the for profit provider Baristas, owned by a } \\
\text { parent company specialising in bar management at } \\
\text { major festivals and outdoor events in the UK. } \\
\text { - Volunteer's role: Bar staff (e.g. serving } \\
\text { customers, preparing drinks, collecting glasses). } \\
\text { Site } 3 \text { - Reading, Berkshire (UK) } \\
\text { - } 6 \text { unpaid volunteers and } 1 \text { team leader, members } \\
\text { of the not-for-profit provider Bars for Equality, } \\
\text { owned by a London-based union. } \\
\text { - Volunteers' role: Bar server (e.g. pulling pints } \\
\text { and serving drinks) }\end{array}$ & $\begin{array}{l}\text { Explore how participants make sense of their } \\
\text { experiences as a 'Green messenger' (i.e. volunteers } \\
\text { involved in recycling). Whether volunteers perceive } \\
\text { work as imbued with meaningfulness (e.g. having } \\
\text { an impact on environmental support) or as } \\
\text { precarious and exploitative work (e.g. the monotony } \\
\text { of litter picking throughout the festival area) and } \\
\text { strategies of coping, subverting or re-imagining } \\
\text { their experience. } \\
\text { Explore participants' experiences as bar staff. } \\
\text { Experiences of meaningfulness (e.g. real sense of } \\
\text { camaraderie and personal closeness) or of } \\
\text { precarious and exploitative work (e.g. the } \\
\text { instrumental use of volunteers to make a profit) and } \\
\text { strategies of coping, subverting or re-imagining } \\
\text { their experience. }\end{array}$ \\
\hline Interviews & $\begin{array}{l}7 \text { interviews with a) } 2 \text { staff coordinators; b) } 4 \text { on- } \\
\text { site managers from the three providers; c) } 1 \text { Chief } \\
\text { of Sustainability at the company organising } \\
\text { Latitude and Reading festivals }\end{array}$ & $\begin{array}{l}\text { Understand processes and procedures of volunteers' } \\
\text { management and recruitment, agreements that they } \\
\text { have with festival organisers for the employment of } \\
\text { volunteers and the provision of their services; } \\
\text { Triangulate conversations and observations. }\end{array}$ \\
\hline $\begin{array}{l}\text { Archival sources } \\
\text { and other } \\
\text { materials }\end{array}$ & $\begin{array}{l}\text { Instruction materials from providers } \\
\text { Application forms completed for recruitment and } \\
\text { training information: Staff guidebooks; (e.g. } \\
\text { instructions about roles, duties, shifts, uniforms, } \\
\text { etc.) Staff code of conduct; Volunteers' info pack } \\
\text { (camping, arrival and registration, food, health \& } \\
\text { safety); Site map and emergency access. } \\
\text { Archival sources } \\
\text { 1. Materials on festival organisers } \\
\text { Financial statement and corporate report on the } \\
\text { company organising Latitude and Reading festival } \\
\text { 2. Materials on the three volunteers providers' } \\
\text { websites, consultation and publically-available } \\
\text { documents } \\
\text { 3. Newspapers and specialised website on } \\
\text { festivals. } \\
\text { Electronic articles on volunteering at festivals } \\
\text { from UK mainstream newspapers, special inserts } \\
\text { on festivals from newspapers (e.g. The Guardian); } \\
\text { consultation of specialised websites that collate } \\
\text { festivals' information (e.g. efestival) }\end{array}$ & $\begin{array}{l}\text { Contextualise observations and interviews by } \\
\text { collecting details on one of the major festival } \\
\text { organisers in the UK } \\
\text { Track the history and the present-day activities of } \\
\text { each organization. } \\
\text { Contextualize festival domain and gain insights into } \\
\text { how the media understand the volunteering } \\
\text { experience at festivals. }\end{array}$ \\
\hline $\begin{array}{l}\text { Visual } \\
\text { Observations }\end{array}$ & $\begin{array}{l}\text { A set of photos } \\
42 \text { Photos taken at Latitude, Camp Bestival and } \\
\text { Reading festival, documenting the sites and the } \\
\text { moments of work and free time with fellow } \\
\text { volunteers. }\end{array}$ & $\begin{array}{l}\text { Support documentation during all phases of on-site } \\
\text { observations }\end{array}$ \\
\hline
\end{tabular}




\section{Theoretical \\ Conceptual \\ Examples from Data and Observations \\ concept}

\section{Work as}

Commodity
Volunteering as Commodification and Control

I didn't know that you could be hired by the company and be paid. On their website this is not clear, or at least it is not clear that you can end up being the worst treated. Also it is unfair that they ask us to stay longer or to clean after bars close. And this is just because they have our deposit! (Jane, volunteer for Baristas).

We never had cameras in the past, while now you really feel that you're always under check (Jim, volunteer for Bars for Equality).

They [volunteers] started as stewards..... you would have a route through to supervisor, the shift leader, perhaps as a coordinator, but that wouldn't make you a business manager. (Anna, Festival Team Manager - Stewards against Unfairness).

Instead, people who do this type of job for their whole life get trapped in a tough routine. Sometimes, this happens because you don't have a degree and can't aspire to anything better. It is important to use these types of job just for achieving something better, but not forever (Vince, volunteer for Recycling First).

My stewards [volunteers] provide a valid and viable commercial offering.... obviously they're not always professional stewarding providers at a festival. So they need advice. So we provide advice on their stewarding requirements.

It happened to me that, after three hours of a shift, I took a cigarette break after securing the permission of my team leader (cigarette breaks and rest breaks were given by the team leader). While I was leaving the bar, I was stopped by a bar supervisor who asked me questions about my breaks and if I had asked the permission of my group leader. I immediately felt embarrassed by the question because I perceived a lack of trust. My natural instinct was to go back to work without saying anything.

Time is considered as a commodity to be managed by the organizers. To respect the volunteers, I insist on business practices that mean we always get money for their time.

Volunteering as

Tedium and

Drudgery

I was sitting in a circle together with three people that had just started their morning shift. We needed to tie plastic bags together in order to distribute them to campers for recycling. This was a very simple task and, after two hours of doing this, Vince, a fellow volunteer, made some observations on the nature of this work. The fact that he was performing this mechanical task during the festival proved that, for him, working at festivals was part of a different regime from normal working life.

One of the most frequently occurring questions among volunteers is about the time. 'What time is it?' People look at their watch and then ask the other volunteers with whom they are doing their shift. Besides the long hours of each shift, this is also a way to build up a sense of being part of the same tribe of people. Sharing the 6-hour shift means also sharing the hard work (Researcher, volunteering at Recycling First).

Work as the

Price of Play
This is the area where the staff are. You can see that there are myriad different organizations with their own camping area, and everyone is backstage to make all this real.

The conditions are stated in a clear manner; it is not possible to make mistakes. And then I am surprised when volunteers don't respect these conditions. It happened, believe me, and she said that I had to cut the volunteers' wristbands and cut them off from the festival (Liz, Chief of Sustainability Office - Festival Organizer). 


\section{Work as \\ Communitas \\ Work as \\ Liminality and \\ Communitas}

Communitas as

Meaningfulness

within the Work

Experience
Will I be perhaps an English teacher abroad? Will I take a year off? The truth is that for now I am very happy to share this experience with new friends and have fun. This means a lot to me (Emma, volunteer for Recycling first).

As I learn, the goodwill of volunteers is essential when it comes to dealing with clients. Due to the nature of our voluntary work, some servers are not actually trained to deliver a decent level of customer service. Often, volunteers are quite slow at taking orders, and bars tend to be quite crowded with long queues. In these circumstances, the poor service is quite often counterbalanced by the friendly and genuine attitude of volunteers. Together with the generally festive atmosphere of the festival, goodwill and kindness become the tenets upon which the organizations rely.

I worked with a group of volunteers who were quite inexperienced at bartending work, and despite the job being quite intuitive, for those who had never served behind a bar, it was quite challenging taking orders, pouring the right quantity of alcohol and serving it to the customers. As I learned very soon, the help of experienced colleagues who were actually those who took care of the less experienced ones was crucial. In fact, as I soon discovered, Baristas counted on the informal help of trained people who taught new volunteers how to serve alcohol and make cocktails.

There is a sheer pleasure of consuming music among volunteers, and often music is a topic of discussion which ties people together. During my shifts, I often spoke about the lineup for the year and this reinforced the sense of belonging to a community of friends that share a common interest around which to gather (Researcher, volunteering at Bars for Equality).

Socializing is also easier because they are in a compound area that we [the festival organizers] set up with facilities like a kitchen, a safe area where to pitch the tent... So, we give them the possibility to stay together and gather around the common arena. I think that when they come to our festivals, they have the feeling that they are sharing an experience (Liz, Chief of Sustainability Office - Festival organizer)

I had this massive rucksack on my shoulders and it was raining and I was very tired from walking. I walked for more than an hour from one gate to another. I was lucky because two ladies were driving and they saw me and they asked me if I needed a lift. You know they were sympathetic. I have this long hair and I resembled Jesus and I think I really looked like a good man... and they offered me a lift and also a bottle of water. You cannot imagine how good I felt after that when they dropped me off just at the right gate (Lawrence, volunteer for Baristas).

This year we are a great team! We are going to enjoy the festival so much because we are so energetic and we are a team that likes laughing and smiling. Yesterday night we had so much fun and that means that we are getting on very well together. We will enjoy this festival (Dave, volunteer for Bars for Equality).

With my fellow volunteers, it was decided to go shopping and celebrate the arrival night with a dinner and some drinks. We left the BFE camping area and we headed together to the supermarket; on our way to the market, a very friendly atmosphere spread out: everyone was talking, as if we had known each other for ages and, once inside the supermarket, communal shop was carried out with food, beers and the alcohol that we needed until the end of the festival. Conversations among us were quite often a balance about the work and the shifts to do and the sensation of freedom coming from the music. Back to our own communal area, we started to cook with the simple means available at a festival and to make the drinks. During these moments, a collective spirit animated our group and a sense of coalescence took place (Researcher, volunteering at BFE).

Well, actually my friend Penelope brought me into the group and I really wanted to come with her.....we enjoy doing things together. When she asked me to come to the festival with her, I was so excited by the idea of enjoying the vibe of the music with her and a group of friends I'd made on my way. That's awesome!

This sense of communitas as 'archaic' togetherness: the bonfire, a quintessential ritual artefact, invokes the sense of un-differentiation and homogeneity typical of communitas. The description is evocative of what we may define as a 'total community', taking place in a transient space - the festive space. The act of eating together whilst gently cooking food on the fire or playing improvised music reveals the extraordinariness of this space" 
Now I like the idea that here we can actually breathe the same atmosphere. You can be yourself here, you can wear a wig, you can be dressed in the weirdest ways and no one judges you (Andy, friend of Recycling first owner).

\section{Communitas Communitas \\ as Ideology Rhetoric Supporting Free \\ Labour}

Communitas as

counter-rhetoric

You know, providing three hot meals per festival per steward is a significant cost to me, but one which means that I know my stewards are well looked after, and as volunteers I believe I have to look after them well because it's a moral responsibility. But also because if they have a good experience with me they'll come back and if I can keep stewards year after year, my acquisition cost per steward goes down. My retention cost will be much cheaper, so I can do business more effectively (Anna, Festival Team Manager - Stewards against Unfairness)

They [volunteers] come because of their friends, their community groups. It's like they go on holiday together every year. So they camp with the same people and they might only see them, you know, once a year at festivals. It's like Brigadoon riding out of the mist. The festival happens, the community builds and then the festival goes again and that's their one chance in a year to catch up with their festival colleagues (Anna, Festival Team Manager - Stewards against Unfairness)

Well, you know, they are treated very well and with respect. The Festival organizer is flexible with them and if volunteers want to change a shift they can discuss it with me or other supervisors. Sometimes, it happens that we have very motivated volunteers, and I always search for motivated volunteers to work with (Liz, Chief of Sustainability Office - Festival organizer).

When volunteers are committed to the cause of the organization that they work for, they are full of enthusiasm, happiness and joy, and when they are like that, sometimes I don't even ask them to pay the deposit. Again, you see, trust is crucial. When people trust each other, there is definitely a different level of commitment, and also the interaction with volunteers is different. You don't have to be vigilant all the time! (Liz, Chief of Sustainability Office - Festival organizer).

We have a lot of volunteers who come to the office who do everything from working on our database to helping us move equipment to, you know, any, any job that you can think of. We trust our volunteers wholeheartedly, our office volunteers are part of our team (Anna, Festival Team Manager - Steward against Unfairness).

They call themselves the XX [name of the provider] family. And their interactions year round are amazing. The forum carries on all year. Facebook is there all year. We have gatherings and meetings throughout the year. So there is a real sense of community as well. I think that's very important. And it makes them do a better job as far as I'm concerned because they look after each other and support each other (Anna, Festival Team Manager - Stewards against Unfairness).

For example, one thing that's become much more common now than maybe 10 years ago is absconding - people abscond. So people will come along work- to say they're gonna work in a bar or if they get the pass we camp them, and all the rest of it, and then we don't see them again because they've got into the festival (Patrick, Chair of the Bars for Work in a bar or if they get the

I want to do my shift and then I want to enjoy the music. Nowadays festivals are too expensive. I am someone who has always liked to go to festivals and Glastonbury is always the best for me. But I can't afford such an expensive ticket now and volunteering with these people [Baristas] allows me to enter for free (Mia, volunteer for Baristas).

. so we've struggled very hard over the years to try and keep that political control because we know, the moment you lose that, you know, it just becomes a hollowed-out operation. It's not been easy, it's a really difficult political battle, because people will say anything to get in to Glastonbury (Patrick, Chair of the Bars for Equality political committee)

I came because I need to be busy, keep myself busy. I am at the age where you can easily feel old, I am 50!! I am involved in many environmental projects and I am committed to them. I feel I need to keep my mind focused (Rachel. Volunteers for Recycling First). 
Table III. Festival Work Framings as Exchange, Communitas, and Ideology

\begin{tabular}{|c|c|c|c|}
\hline $\begin{array}{l}\text { Framing of } \\
\text { Work }\end{array}$ & Exchange/Commodity & Communitas as Value & Communitas as Ideology \\
\hline $\begin{array}{l}\text { Relation to } \\
\text { Meaningful Work }\end{array}$ & $\begin{array}{l}\text { Work lacking } \\
\text { Meaningfulness }\end{array}$ & $\begin{array}{l}\text { Meaningfulness through } \\
\text { Unity and Solidarity }\end{array}$ & $\begin{array}{l}\text { Instrumentalization of } \\
\text { Meaningfulness }\end{array}$ \\
\hline $\begin{array}{l}\text { Goals of Festival } \\
\text { Work }\end{array}$ & $\begin{array}{l}\text { Exchange value, } \\
\text { consumer experience }\end{array}$ & $\begin{array}{l}\text { Togetherness/ relational } \\
\text { value, social mission }\end{array}$ & $\begin{array}{l}\text { Legitimation of cheap } \\
\text { labour (management), } \\
\text { networking, free/improved } \\
\text { access (workers) } \\
\end{array}$ \\
\hline $\begin{array}{l}\text { Work/non-work } \\
\text { Relation }\end{array}$ & Antagonistic & Harmonious/Synergistic & Cynical/ironic \\
\hline $\begin{array}{l}\text { Type of social } \\
\text { action }\end{array}$ & Rational/economic & Social cooperative & Social-performative \\
\hline Use of festival space & Festival as market & $\begin{array}{l}\text { Festival as Communal } \\
\text { Ritual }\end{array}$ & $\begin{array}{l}\text { Festival as performative } \\
\text { spectacle }\end{array}$ \\
\hline $\begin{array}{l}\text { Relation between } \\
\text { workers/organizers }\end{array}$ & $\begin{array}{l}\text { Asymmetric exchange } \\
\text { partners }\end{array}$ & Cohesive community & Complicit opportunistic \\
\hline $\begin{array}{l}\text { Type of worker } \\
\text { coordination/control }\end{array}$ & Market-exchange & Cultural, values-driven & Neo-normative \\
\hline
\end{tabular}


Figure 1. Working under pressure in a branded Bar

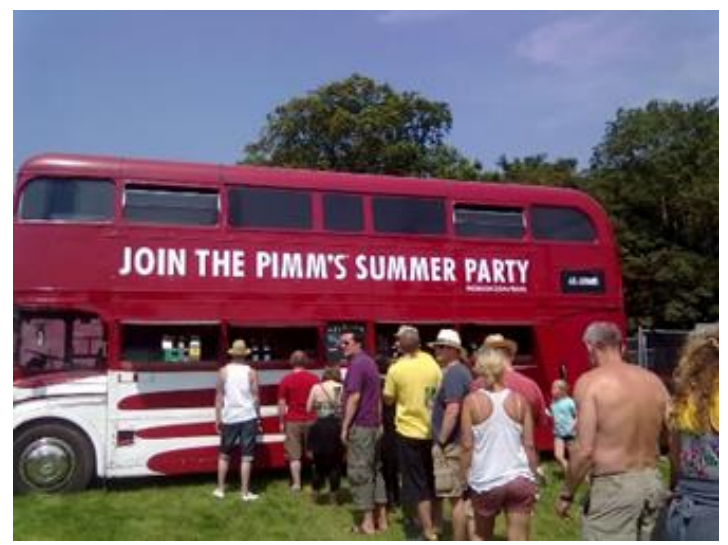

Figure 2. Tying together plastic bags

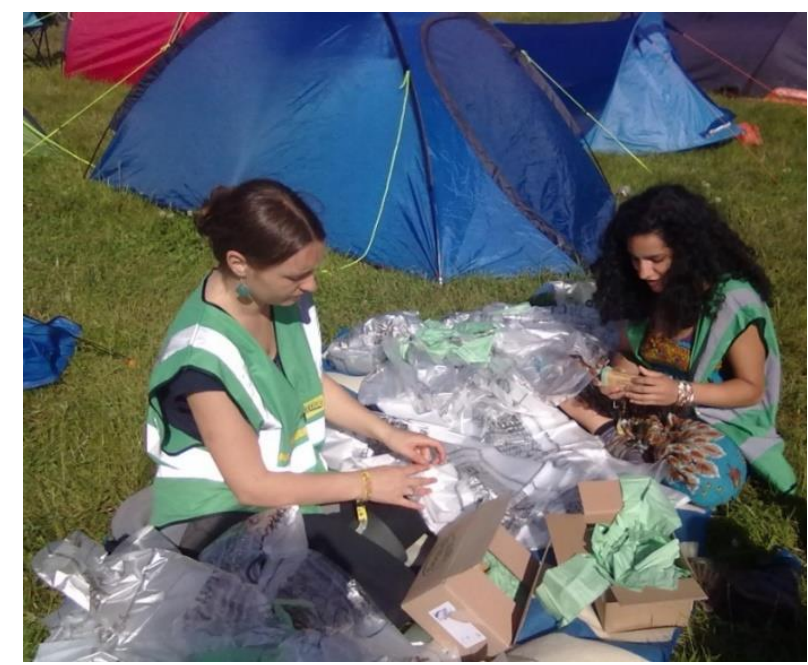

Figure 3. Moment of getting off work to redeem free drinks

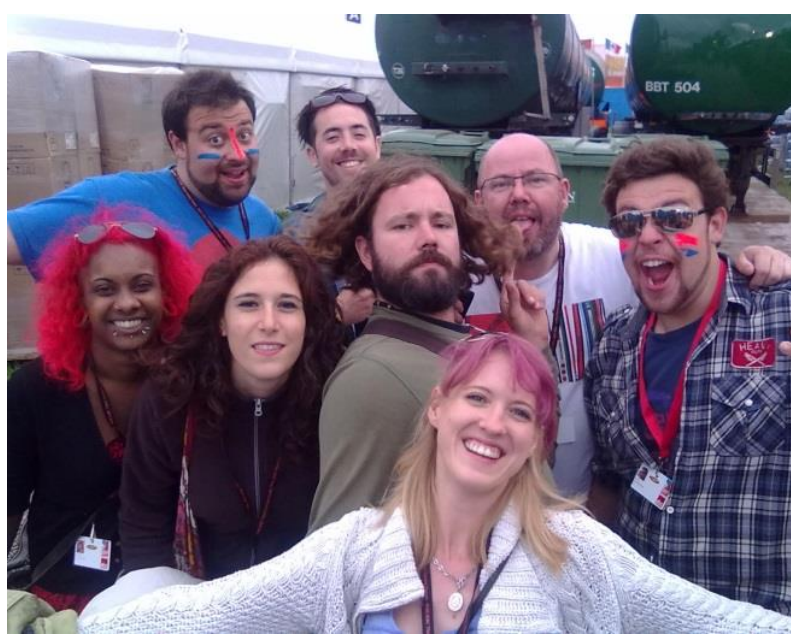

Figure 4. Communal bonfire among workers

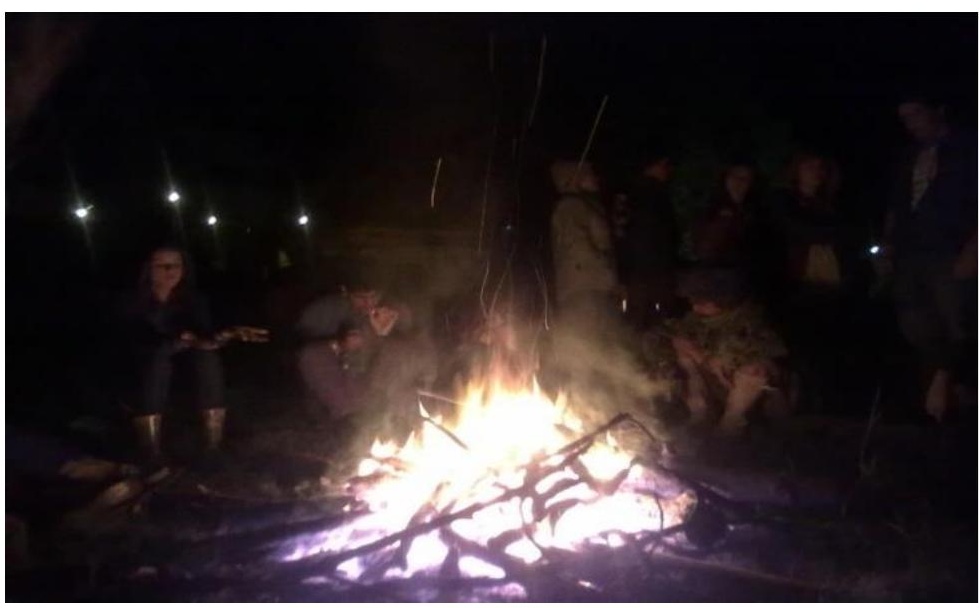

Figure 5. After-shift tent for communal dining and cooking

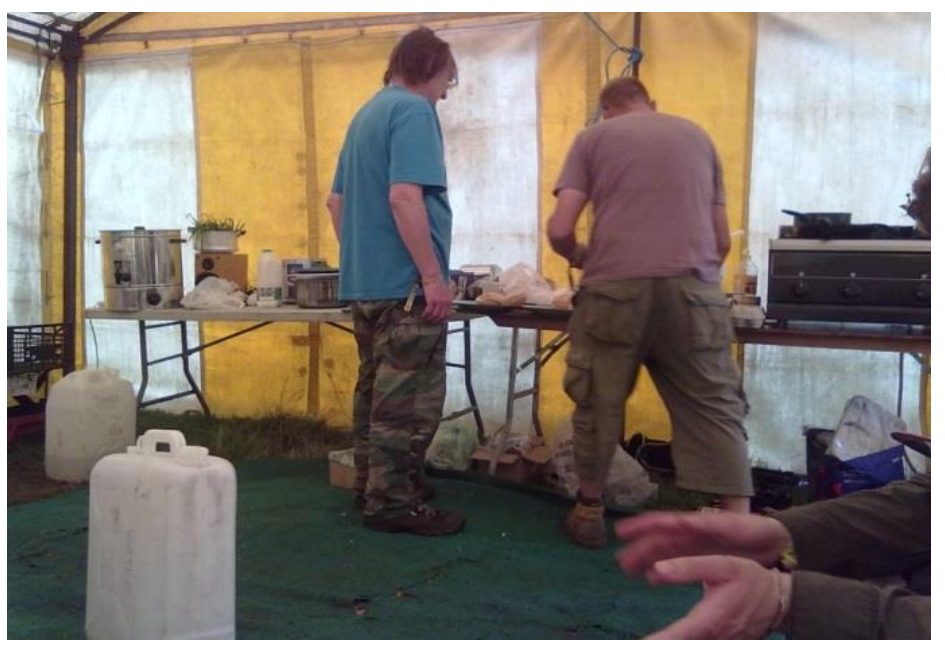


Figure 6. Volunteer work as Exchange, Communitas and Ideology

Volunteer work as Commodity

-Work and Meaning considered as separate spheres

-Exchange relationship applies (production for consumption)

\section{Work}

\section{Meaningfulness}

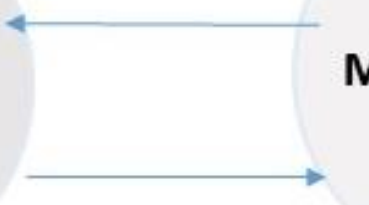

$\longleftrightarrow$

Volunteer work as Communitas

-Work and Meaning considered

as unified

\section{Work Meaningfulness}

-Boundary between spheres

dissolved, work and meaning

considered liminal experiences

\section{Volunteer work as ideology}

-Meaningfulness discourse

hides underbelly of material

production

-Work legitimated by

meaningfulness

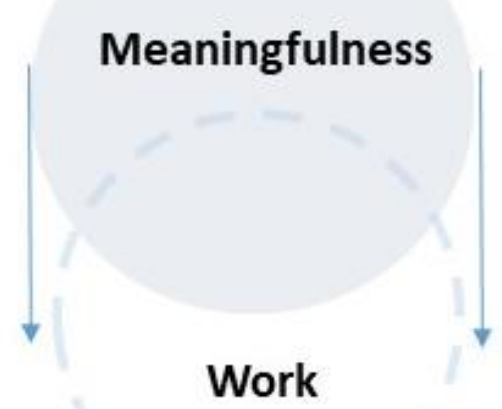

